\title{
Pig Droppings: A Potential Biostimulatory Candidate for Bioremediation of Diesel Oil- Polluted Soil
}

\section{Kingsley Tochukwu Ughamba ${ }^{1,2, *}$, Nnabueze Darlington Nnaji ${ }^{2}$, Kenneth Ejike Ogbonna $^{1,3}$, Chukwudi Uzoma Anyanwu ${ }^{2}$}

\author{
${ }^{1}$ Department of Science Laboratory Technology, University of Nigeria, Nsukka \\ ${ }^{2}$ Department of Microbiology, University of Nigeria, Nsukka \\ ${ }^{3}$ Department of Biochemistry, University of Nigeria, Nsukka \\ *Corresponding author:
}

\begin{abstract}
The effectiveness of pig droppings (PD) in enhancing bioremediation of diesel oil-polluted soil was investigated gravimetrically for a period of 42 days. Polluted soil was amended with 5\%, 10\% and 15\% (w/w) of PD. Loss of total petroleum hydrocarbon (TPH), microbial growth and germination indices were all monitored throughout the study period. At the end of 42 days, there was significant oil loss of $48.54 \%$ in the amended soil. Hydrocarbonutilising bacterial (HUB) counts were higher in the amended option ranging from $4.2 \times 10^{6} \pm 0.69$ to $10.9 \times 10^{6} \pm 0.41$ CFU/g. The HUB isolated from the oil-contaminated soil were identified tentatively as Bacillus cereus, Pseudomonas putida, Micrococcus varians, Corynebacterium sp and Staphylococcus sp. Similarly, fungal counts ranged from $3.0 x$ $10^{5} \pm 0.21$ to $10.9 \times 10^{5} \pm 0.33 \mathrm{CFU} / \mathrm{g}$. Aerobic fungi isolated were identified tentatively as Aspergillus niger, Aspergillus flavus, Fusarium sp, Cladosporium sp and Penicillium sp. Germination index of 53.4\% was recorded in the amended option. Oil loss and microbial growth were significantly higher $((P \leq 0.05)$ in the amended option than the control option. Pig droppings, therefore can offer a good alternative in bioremediation of diesel oil-polluted soil.
\end{abstract} Keywords—Bacteria, fungi, pig droppings, bioremediation, diesel oil, pollution.

\section{INTRODUCTION}

The global reliance on petroleum products for source of energy has markedly engendered pollution of the aquatic and terrestrial systems [1]. Environmental pollution due to petroleum products always occurs due to accidental spills or anthropogenic mishap. The impact of hydrocarbon pollution can have serious and far-reaching effects on all life forms. Therefore, several strategies had been developed over the years to combat the menace of incessant oil spills. The scale of hazards imposed on the natural environment depends on the surface of the area contaminated by the petroleum products, their chemical composition, and the depth at which pollutants occur [2]. For this reason an increasing attention has been directed towards the research for new strategies and environment-friendly technologies to be applied in the remediation of soil contaminated by petroleum hydrocarbons. Physical and chemical approaches to hydrocarbon remediation are expensive and ecotoxic [3]. Bioremediation technology which involves the use of life forms to detoxify or remove pollutants through the mechanisms of biodegradation has been found to be ecofriendly, noninvasive and relatively cheaper [4]. Microbial remediation which involves the use of microorganisms to clean up contaminated soils has gained wide acceptance. However, while organisms utilize hydrocarbons as carbon source, they need other nutrients such as nitrogen and phosphorus for their growth and activities. It stands to reason, therefore, that insufficiency of nutrients in the right proportions is the bane of microbe-based bioremediation strategies. Knowledge of the aforementioned fact induced the scientific community to look out for materials that can enhance the growth and activities of hydrocarbonutilising microbes. Many agricultural wastes have been used to stimulate the activities of different hydrocarbon-utilising microbes [5, 6, 7]. Specifically, few works have been done on using pig droppings to stimulate the bioremediation of diesel oil-polluted soil. This work was therefore designed to assess the biostimulatory potential of PD in enhancing bioremediation of diesel-oil polluted soil. 


\section{MATERIALS AND METHODS}

\section{Collection and Processing of Samples}

Soil sample used in this study was collected from an agricultural land from different sites in Obukpa, Nsukka, South east, Nigeria at a depth of 0-30 cm. The soil sample was air dried and sieved through a $2 \mathrm{~mm}$ mesh. Diesel oil was bought from TOTAL filling station in Nsukka metropolis while the pig droppings (PD) was collected from a household farmer in Nsukka, Southeast, Nigeria.

\section{Physicochemical Analyses Soil and Pig Droppings}

Physicochemical properties of soil and pig droppings were determined using standard methods [8]: Particle size distribution of the soil, total nitrogen, available phosphorus of the soil sample and total phosphorus of the pig droppings, $\mathrm{pH}$, moisture and total organic carbon (TOC) were all determined. Triplicate determinations were made for each assay.

Determination of the Extraction Efficiency of Different Solvents for Diesel Oil

Three different organic solvents namely dichloromethane, nhexane and diethylether were used to extract diesel oil and their extraction rates determined. The best solvent in terms of extraction efficiency for diesel oil was later used for the bioremediation assay. The extraction efficiency was determined gravimetrically. Briefly, forty grammes of the soil sample was transferred into a $250 \mathrm{~mL}$ flask and polluted with $4 \mathrm{~mL}$ of diesel oil. A $4 \mathrm{~mL}$ quantity of diesel oil was used so as to simulate a $10 \%$ pollution condition that would be studied in the present work. A $100 \mathrm{~mL}$ quantity of the three organic solvents was added separately to each polluted soil sample setup and the set-ups shaken for six hours at $180 \mathrm{rpm}$. The solution was then filtered using a Whatman No 4 filter paper and the weight of the extracted oil recorded. The extraction efficiency of the organic solvents for diesel was then determined by weight difference following the formula [9]. The experiment was carried out in triplicates.

Extraction efficiency $=$ Weight of $4 \mathrm{~mL}$ diesel oil - Weight of oil extracted from soil $\times 100$ Weight of $4 \mathrm{~mL}$ diesel oil

\section{Soil Preparation for Bioremediation Study}

A $1 \mathrm{~kg}$ quantity of soil was air -dried for two days and sieved with $2 \mathrm{~mm}$ mesh size. Soil sample was then placed in sterile polythene bags and $10 \%(\mathrm{v} / \mathrm{w})$ of diesel oil was added separately, thoroughly mixed, and left undisturbed for 48 hours. After two days, 5\%, 10\% and $15 \%$ of pulverized PD were respectively introduced separately to diesel oil-polluted soils and thoroughly mixed. Soil contaminated with $10 \%$ (v/w) diesel oil without PD amendment served as control. The moisture content of the soil was adjusted to $60 \%$ water holding capacity by the addition $50 \mathrm{~mL}$ of sterile distilled water (three times weekly) and the set-up kept at room temperature $\left(28 \pm 2^{\circ} \mathrm{C}\right)$. The experiment was set up in triplicates.

Determination of the level of diesel oil loss from polluted soil

Periodic sampling from each polythene bag was carried out every seven days in order to determine the residual diesel oil. A slight modification of the gravimetric and spectrophotometric methods [6] was employed in the determination of residual diesel oil present in both the control soil and amended options: Composite polluted soil samples weighing ten grammes were put in a $100 \mathrm{~mL}$ flask and $50 \mathrm{~mL}$ of n-hexane was added. N-hexane was used owing to its highest extraction efficiency for diesel oil among other solvents (see result section). The set-ups were shaken with a rotary shaker at $180 \mathrm{rpm}$ for 10 hours to allow for an efficient and complete oil extraction with $n$-hexane. The mixture was then filtered with a whatman No 4 filter paper. A two-step filtration was done to ensure complete extraction of the liquid phase. The filtrate was diluted by adding $50 \mathrm{~mL}$ of $\mathrm{n}$-hexane to $1 \mathrm{~mL}$ of the extracted diesel oil and the absorbance of the solution measured at $460 \mathrm{~nm}$ (Shimadzu UV 1800) using nhexane as blank. The total petroleum hydrocarbon (TPH) was estimated by extrapolating from a standard curve derived from different concentrations of fresh diesel oil diluted with nhexane. Percent remediation (R) was calculated using the following formula:

$$
\mathrm{R}=\frac{T P H i-T P H r}{T P H} \times 100
$$

Where $\mathrm{TPHr}$ and TPHi are residual and initial TPH concentrations

\section{Enumeration and Identification of Heterotrophic Microbes}

Ten grammes of soil sample from the amended options and the control option was introduced into $90 \mathrm{~mL}$ of distilled water and shaken vigorously for proper mixing of the sample. A 0.1 $\mathrm{mL}$ aliquot of the appropriate dilution of the suspension was inoculated on sterile nutrient agar plates by the spread plate method for aerobic heterotrophic bacteria [10]. The nutrient agar medium was supplemented with $50 \mu \mathrm{g} / \mathrm{mL}$ nystatin to suppress the growth of fungi. The agar plates were incubated at $35^{\circ} \mathrm{C}$ for $24 \mathrm{~h}$ after which colony forming units (CFU) per gram of soil samples were calculated. Three replicate samples from each oil-polluted soil were withdrawn every 7 days for the enumeration of total aerobic heterotrophic bacteria (AHB). Hydrocarbon utilizing bacteria (HUB) in the soil samples were 
enumerated by plating on Bushnell Has medium, $\mathrm{pH}$ 7.4, using the vapour phase transfer method as described [11]: A filter paper saturated with sterile diesel oil was aseptically placed on the inside of the cover of inverted inoculated petri dishes and incubated at $28^{\circ} \mathrm{C}$ for 7 days. Distinct colonies of hydrocarbon-utilizing bacteria were picked and pure isolates obtained by repeated sub-culturing on nutrient agar. The bacterial isolates were characterized using microscopic techniques and biochemical tests such as catalase, urease, oxidase, starch hydrolysis, spore forming, $\mathrm{H}_{2} \mathrm{~S}$ production, motility, citrate utilization and methyl-red tests.

For the isolation and enumeration of fungi, $0.1 \mathrm{~mL}$ of the appropriate dilution of each of the set-ups was inoculated into Sabouraud Dextrose Agar (SDA) plates and incubated at $28 \pm 2^{\circ} \mathrm{C}$ for 4 days. Colony counts were taken and pure isolates obtained by repeated sub-culturing on SDA plates. The fungal isolates were characterized by slide culture and microscopic techniques and identified by the schemes [12].

\section{Seed Germination Toxicity Test}

The polluted soil amended with PD and unamended control soil were subjected to seed germination test, post remediation period following the method [13]. Seeds of Phaseolus vulgaris (common bean) were used. Briefly, $40 \mathrm{~g}$ of thoroughly-mixed remediated soil samples from both the control soils and the amended soil was placed in $100 \times 15 \mathrm{~mm}$ petri-dish. Six viable seeds were placed evenly throughout each Petri dish and covered with $10 \mathrm{~g}$ of dry sand. The moisture content of the setups were maintained at $60 \%$ water holding capacity. Triplicate determinations was made for each assay. At the end of 10 days, the number of seeds that germinated from the surface of the soil was counted and root length measured to the nearest centimeter using a metre rule. The results were evaluated using the formula [14] with slight modification. Soil neither polluted nor amended served as the positive control soil while polluted soil without amendment served as negative control.

- Germination index $(\%)=(\mathrm{SG} \times \mathrm{LR}) / 100$

- $\mathrm{SG}=(\mathrm{ET} / \mathrm{CG}) \times 100$

- $\mathrm{LR}=(\mathrm{LRT} / \mathrm{LRC}) \times 100$

Where $\mathrm{SG}=$ number of seed germination, $\mathrm{LR}=$ root length (elongation), ET=number of seeds that germinated on treated soil, $\mathrm{CG}=$ number of seeds that germinated on positive control soil, LRT= root length on treated soil, LRC=root length on positive control soil.

\section{Statistical Analysis of Data}

The data obtained in the present study were subjected to oneway analysis of variance (ANOVA). Relationship between variables and comparison of means of the different treatments were tested for level of significances at $\mathrm{P} \leq 0.05$ using least square difference and post-hoc multiple comparison tests. The data analysis was performed using SPSS.

\section{RESULTS}

\section{Physicochemical Properties of Soil and Pig Droppings}

The physicochemical properties of the soil and pig droppings used in this study are presented in Table 1 . The percentage organic nitrogen content of the soil was 0.042 and available phosphorus content of $10.64 \%$. Other parameters of the soil in percentage are: organic carbon 2.49 , moisture 10.38 and the $\mathrm{pH}$ is 4.9. The pig droppings has a $\mathrm{pH} 10.0$ and nitrogen content of 0.238

Table 1: Physicochemical properties of soil and pig

\begin{tabular}{lll}
\multicolumn{3}{c}{ droppings } \\
\hline Parameter & Non-polluted Soil & Pig droppings \\
\hline $\mathrm{pH}$ & $4.90 \pm 0.37$ & $10.0 \pm 0.03$ \\
Nitrogen & $0.042 \pm 0.02$ & $0.238 \pm 0.04$ \\
Organic carbon & $2.49 \pm 0.45$ & $22.94 \pm 0.09$ \\
Phosphorus (PPM) & $10.64 \pm 0.5$ & $22.40 \pm 0.07$ \\
Moisture (\%) & $10.38 \pm 0.3$ & $8.69 \pm 0.229$ \\
Clay (\%) & $71.00 \pm 0.41$ & - \\
Silt (\%) & $19.50 \pm 0.06$ & - \\
Sand (\%) & $9.50 \pm 0.08$ & - \\
Texture & Clayey Loam & \\
\hline
\end{tabular}

\section{Extraction Efficiency of Solvents for Diesel Oil}

The amount of diesel oil (in percentage) that was extracted by three different solvents namely: $n$-hexane, dichloromethane and diethylether six hours after polluting soil with $10 \%(\mathrm{v} / \mathrm{w})$ diesel oil were $80.72 \%, 80.68 \%, 80.56 \%$, respectively.

\section{Bioremediation of Diesel Oil:}

The level of bioremediation in unamended control soil and soil amended with $5 \%, 10 \%$ and $15 \%(\mathrm{w} / \mathrm{w})$ PD over a 42-day period are presented in Figure 1. Percentage oil (TPH) loss in the amended option ranged between 25.83 2.07 and $46.67 \pm 1.32$ across all amendment levels. Oil loss ranging from $19.93 \% \pm 0.96$ to $32.22 \% \pm 0.6$ was recorded in the unamended control soil. 


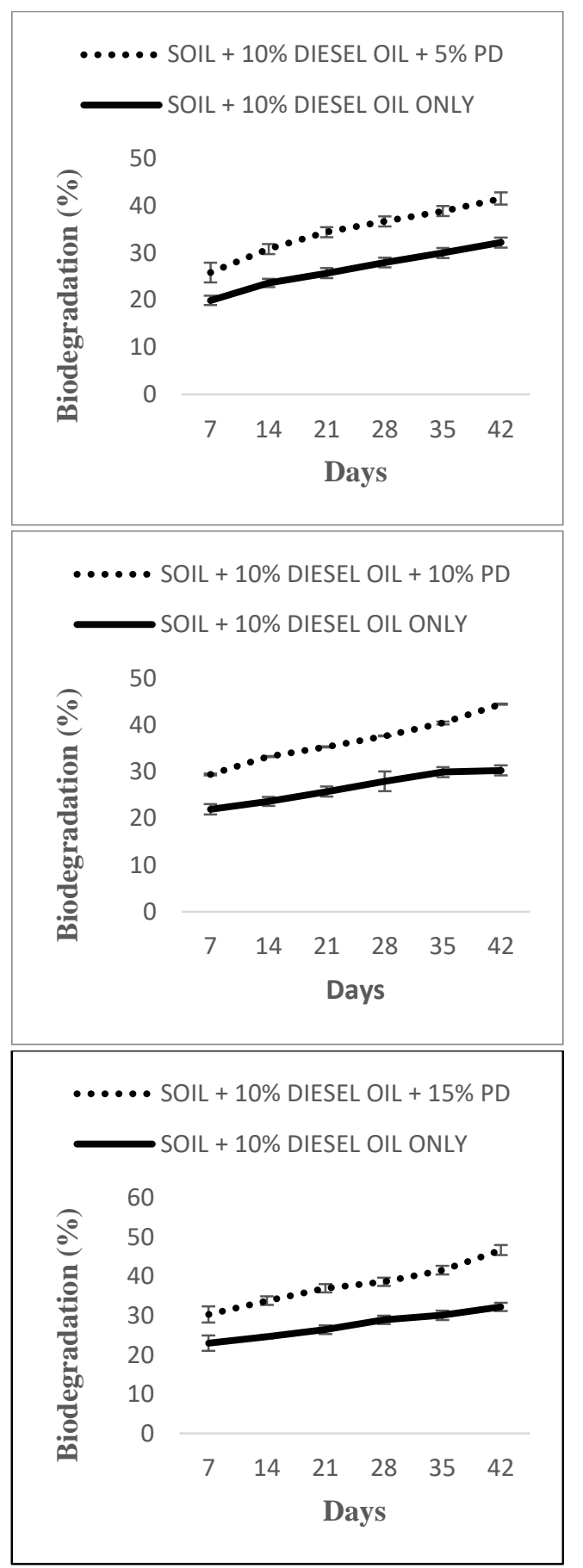

Fig.1: Bioremediation of Diesel Oil in polluted soil amended with 5\%, $10 \%$ and $15 \%(\mathrm{v} / \mathrm{w})$ PD

\section{Enumeration and Identification of Microorganisms} Active aerobic heterotrophic bacteria count:

Active aerobic heterotrophic bacterial (AHB) counts in both the control soil and polluted soil amended with 5\%,10\% and $15 \%(w / w)$ PD is presented in Figure 2. AHB counts ranged between $6.8 \times 10^{7} \pm 0.2$ and $23.8 \times 10^{7} \pm 0.14 \mathrm{CFU} / \mathrm{g}$ across all amendment levels. AHB counts recorded in the unamended control soil ranged between $1.0 \times 10^{7} \pm 0.06 \times 10^{7}$ and $20 \times 10^{7}$ $\pm 0.9 \times 10^{7} \mathrm{CFU} / \mathrm{g}$.

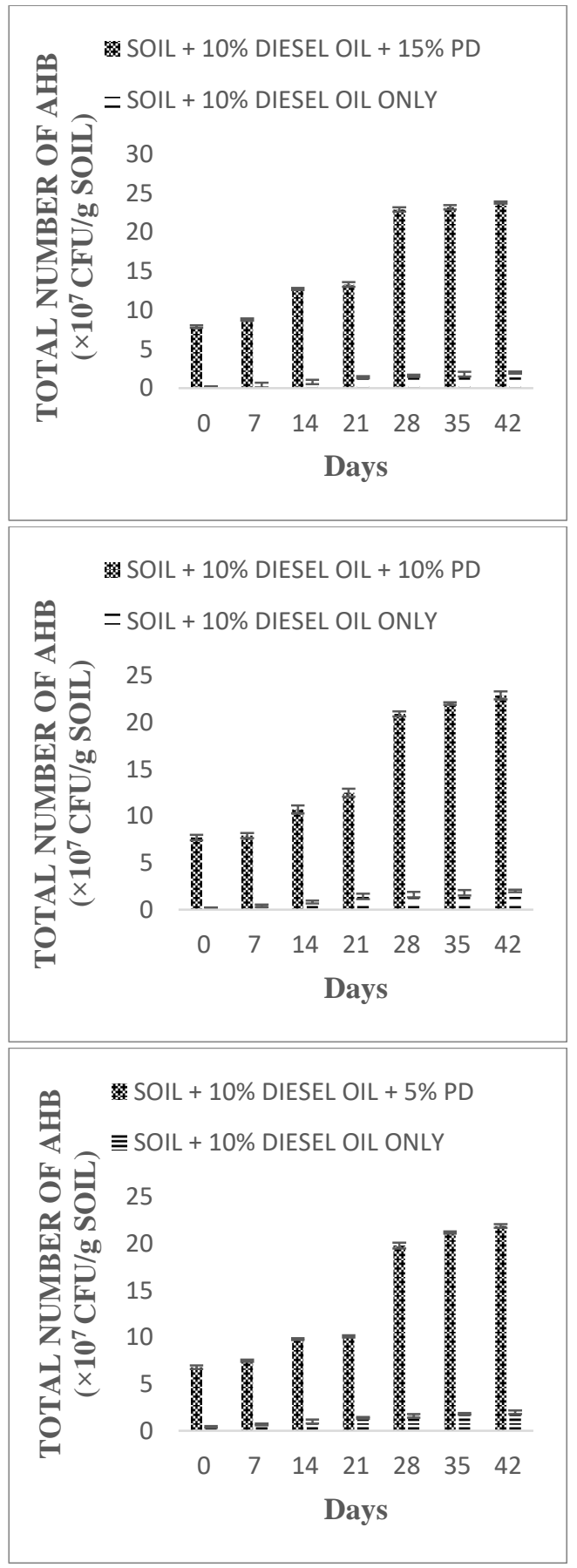

Fig.2: Active Aerobic Heterotrophic Bacteria (AHB) population in polluted soil amended with $5 \%, 10 \%$ and $15 \%$ $(w / w) P D$ 


\section{Hydrocarbon-utilising bacterial count:}

The total number of hydrocarbon-utilising bacteria in unamended control soil and polluted soil amended with 5\%, $10 \%$ and $15 \%(\mathrm{w} / \mathrm{w})$ PD is recorded in Figure 3 ranging from $4.8 \pm 0.2 \times 10^{6}$ to $12.2 \pm 0.23 \times 10^{6} \mathrm{CFU} / \mathrm{g}$ while unamended control HUB population ranged from $0.5 \times 10^{6} \pm 0.08$ to1.5 x $10^{6} \pm 0.03 \mathrm{CFU} / \mathrm{g}$.

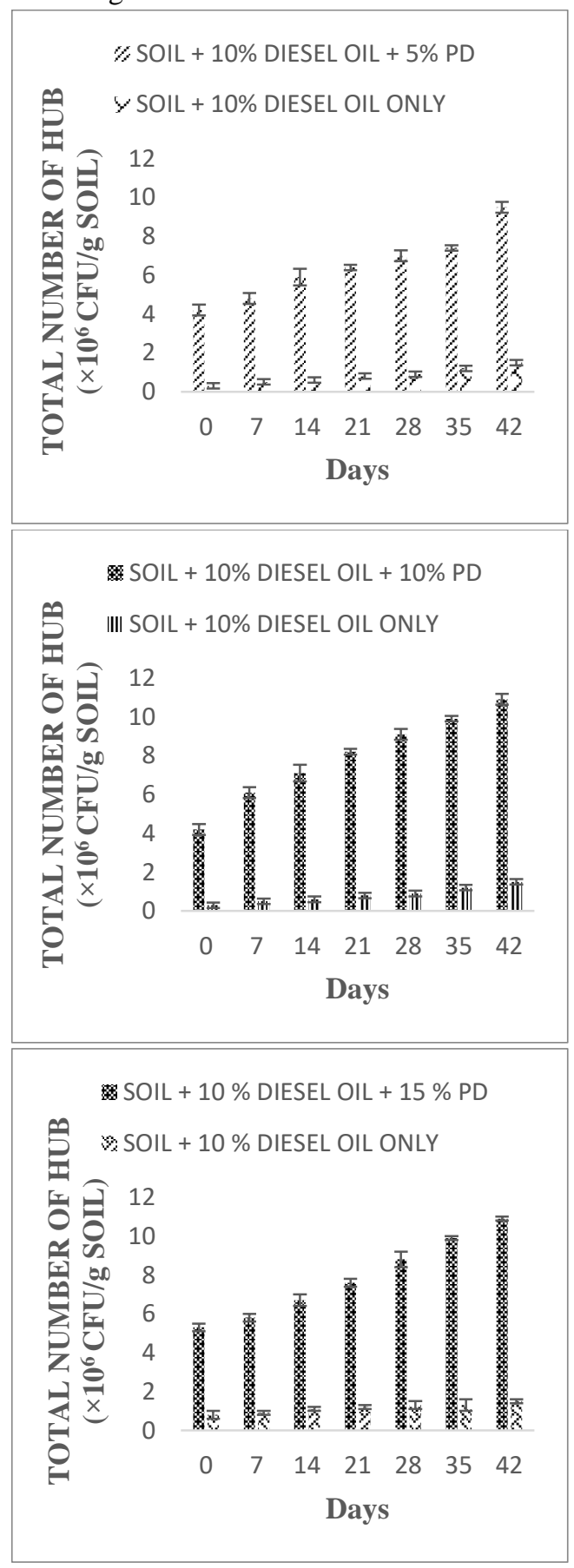

Fig.3: HUB population in polluted soil amended with $5 \%, 10 \%$ and $15 \%(w / w)$ PD

\section{Identities of Bacterial isolates}

The microscopic and biochemical characteristics of the isolated hydrocarbon-utilising bacteria are presented in Table 2. The HUBs are identified tentatively as Bacillus licheniformis, Pseudomonas putida,Corynebacteriumsp., Micrococcus varians, Staphylococcus aureus and Bacillus cereus 
Table 2: Microscopic and Biochemical Characteristics of Bacterial Isolates

\begin{tabular}{|c|c|c|c|c|c|c|c|c|c|c|}
\hline ‡ & 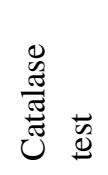 & 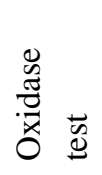 & $\stackrel{\sim}{I}$ & 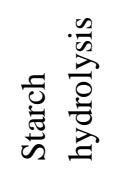 & 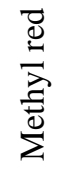 & 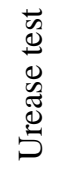 & 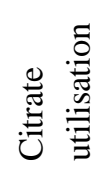 & 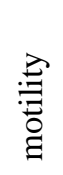 & 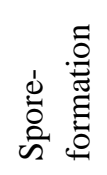 & 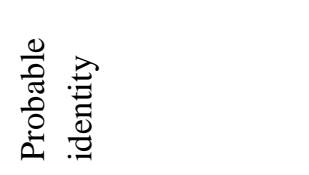 \\
\hline+ & + & - & - & + & + & - & - & + & + & Bacillus cereus \\
\hline+ & + & + & + & - & + & + & + & - & - & Micrococcus varians \\
\hline+ & + & - & - & - & - & - & + & - & - & Staphylococcus sp \\
\hline- & + & + & - & + & - & + & + & + & - & Pseudomonas putida \\
\hline+ & + & + & - & - & - & - & - & - & - & Corynebacterium sp \\
\hline+ & - & - & - & + & - & - & - & + & + & $\begin{array}{l}\text { Bacillus } \\
\text { licheniformis }\end{array}$ \\
\hline
\end{tabular}

\section{Aerobic Fungal Count}

The total number of aerobic heterotrophic fungi in the control option and the PD-amended options is presented in Figure 4. Aerobic fungal counts in the PD-amended option ranged from $3.0 \times 10^{5} \pm 0.1$ to $10.4 \times 10^{5} \pm 0.2$. Aerobic fungal counts recorded in the unamended control ranged from $0.3 \times 10^{5} \pm$ 0.62 and $12.0 \pm 0.7 \times 10^{4} \mathrm{CFU} / \mathrm{g}$.

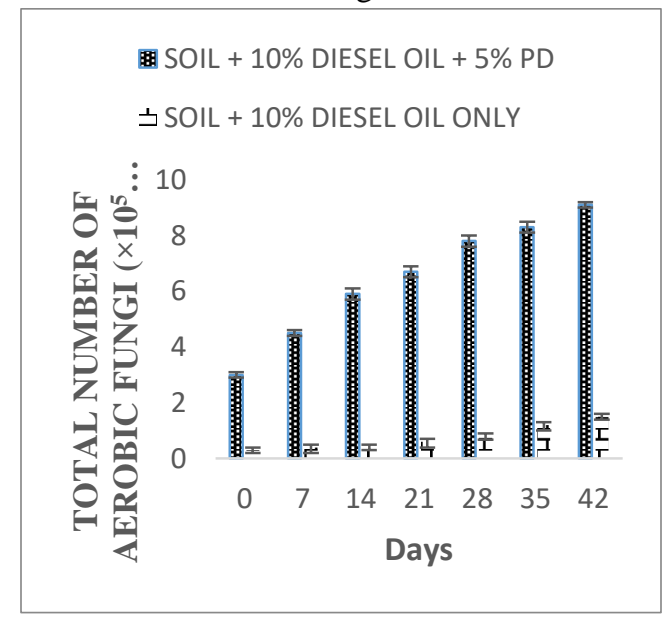

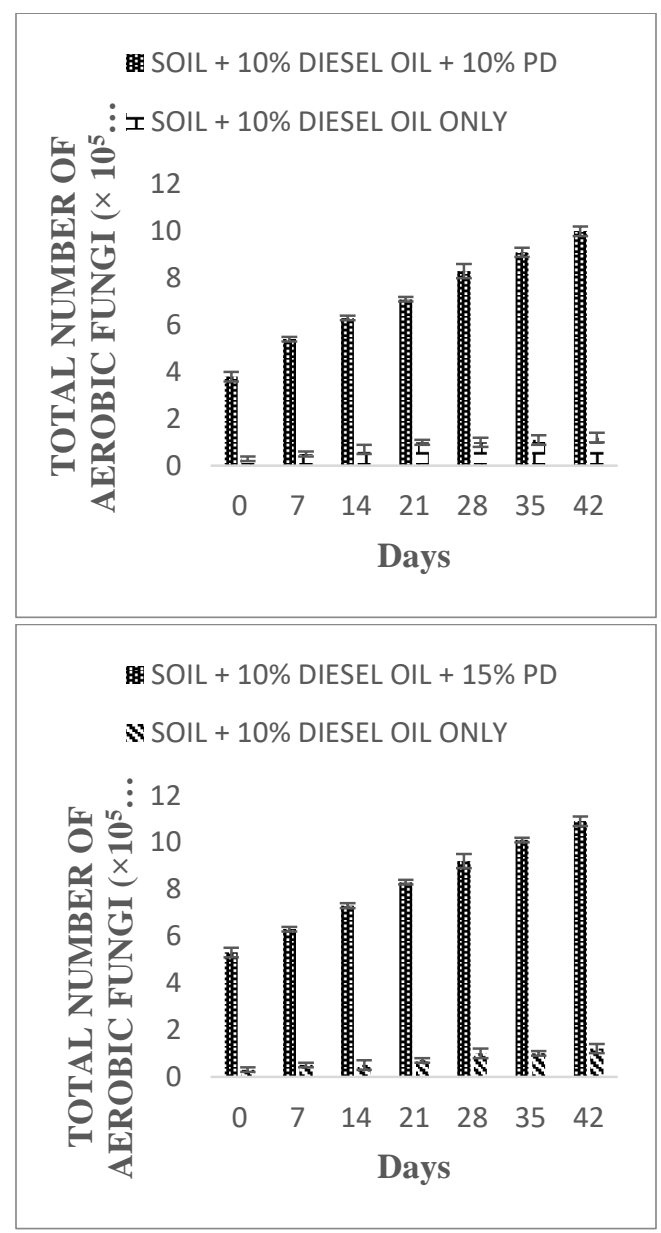

Fig.4: Active Aerobic fungal population in oil polluted soil amended with 5\%, 10\% and $15 \%(w / w) P D$ 
Identities of Fungal isolates

The cultural and microscopic characteristics of the isolated hydrocarbon-utilising fungi are presented in Table 3. Fungi isolated predominantly were identified tentatively as Aspergillus niger, Aspergillus flavus, Fusarium sp., Cladosporium sp. and Penicillium sp

Table 3: Cultural and Microscopic Characteristics of Fungal Isolates

\begin{tabular}{|c|c|c|}
\hline Cultural characteristics & Microscopic Characteristics & Probable Identity \\
\hline $\begin{array}{l}\text { Dark brown, powdery, flat spread on the surface of the } \\
\text { solid medium with reverse }\end{array}$ & $\begin{array}{l}\text { septate and branched hyphae with } \\
\text { conidia in chains }\end{array}$ & Aspergillusspp \\
\hline $\begin{array}{l}\text { Yellow, powdery, flat spread on the surface of the solid } \\
\text { medium with colourless reverse }\end{array}$ & $\begin{array}{l}\text { Septate and branched hyphae with } \\
\text { conidia in chains }\end{array}$ & Aspergillusspp \\
\hline $\begin{array}{l}\text { Grey colonies that were large with white border. } \\
\text { Colourless or white reverse }\end{array}$ & $\begin{array}{l}\text { Long conidiophores consisting of } \\
\text { broom-like conidia in chains }\end{array}$ & Penicilliumspp \\
\hline $\begin{array}{l}\text { Whitish and cottony mycelium with pinkish pigments at } \\
\text { the centre. Brown reverse side }\end{array}$ & $\begin{array}{l}\text { segmented canoe-shaped spores and } \\
\text { branched conidiophores }\end{array}$ & Fusariumspp \\
\hline $\begin{array}{l}\text { Powdery, slow-growing, blackish-brown colonies, } \\
\text { olivaceous-black reverse. Conidiophores and conidia } \\
\text { equally pigmented }\end{array}$ & $\begin{array}{l}\text { Branched and shield-shaped conidia in } \\
\text { chains }\end{array}$ & Cladosporiumspp \\
\hline
\end{tabular}

\section{Seed Germination Profile of Remediated Soil}

The seed germination parameters of soil after a 42-day bioremediation period is presented in Table 4. GI ranged from 15.8 to 53.4 across all amendment levels. Negative and positive control had percentage GI of 2.8 and 100 , respectively. LR (\%) ranged from 47.7 to 80.0 across all amendment levels. Positive and negative control had percentage LR of 100 and 16.9, respectively. Positive and negative controls had \% SG of 100 and 16.7 respectively while $\%$ SG ranged from 33.3 to 66.1 across all amendment levels.

Table 4: Seed Germination Parametres

\begin{tabular}{llllll}
\hline Soil preparations & SG & LR $(\mathrm{cm})$ & SG $(\%)$ & LR $(\%)$ & GI (\%) \\
\hline 5\% PD & 2.0 & 3.1 & 33.3 & 47.7 & 15.8 \\
$10 \%$ PD & 3.0 & 4.0 & 50.0 & 61.5 & 30.7 \\
15\% PD & 4.0 & 5.2 & 66.1 & 80.0 & 53.4 \\
Negative control & 1 & 1.1 & 16.7 & 16.9 & 2.8 \\
Positive control & 6 & 6.5 & 100 & 100 & 100
\end{tabular}

Key: number of seeds that germinated, LR= root length, GI= germination index

\section{DISCUSSION}

This work was carried out against the backdrop of the insufficiency of the use of microbes alone in the bioremediation of diesel oil-polluted soil. It was rightly reported [15] that despite the presence of microbes in hydrocarbon-contaminated soils, their levels might not measure up to that needed for bioremediation of the site, hence the need to stimulate their growth and activities. Lack of nutrients in the right proportions have been identified as the bane of several biostimulation-based bioremediation [16]. Addition of organic wastes to improve the activities of hydrocarbon-degrading microbes has therefore been widely demonstrated $[16,3,6]$.
It has been a common practice by the industrial and household populations to dispose of organic wastes indiscriminately. As can be noted from the present study, PD has potential for stimulating the activities of hydrocarbonutilising microbes in bioremediation processes. In the present study, the percentage organic nitrogen content of the soil is relatively low (Table 1). Organic nitrogen was identified as a panacea to realizing an efficient biostimulation strategy [5]. Also, positive nitrogen amendment in polluted soils has been recorded [6]. This is due to the fact that while microbes utilize hydrocarbons in spills as carbon source, they need adequate concentrations of nutrients such as nitrogen and phosphorus to synthesize important macromolecules such as proteins and 
nucleic acids. Hence, addition of PD with a higher nitrogen and phosphorus content (Table 1) enhanced the activities of the diesel oil-utilising microbes. Furthermore, the $\mathrm{pH}$ of the experimental soil was low (fairly acidic) (Table 1) and therefore ineffective for biodegradation. Low $\mathrm{pH}$ was reported to affect biodegradation of pollutants [17]. In this study, however, the fairly acidic experimental soil was neutralized by the alkaline organic waste, $\mathbf{P D}$ with a $\mathrm{pH}$ of 8.7 since bacterial remediation rates tend to be fastest at neutral $\mathrm{pH}$ [3].

The result of the extraction efficiency experiment clearly indicated that n-hexane was the best choice in extracting diesel oil under the experimental conditions employed in the current study. This is due to the fact that the highest amount of diesel oil was extracted with n-hexane among other solvents such as dichloromethane and diethylether used in this study.

Percentage oil loss (bioremediation) increased tremendously from the first week to the sixth week in all the amended options and the control option. However, highest oil loss was observed at $15 \%$ amendment level (Figure 1). This obviously could be due to an enhanced nutrient level present at the highest amendment level. There was still a notable oil loss in the unamended control soil. Comparative studies on different hydrocarbon pollutants and different amendments obviously recorded different levels of oil loss in both the amended and unamended options [17, 6, 3, 11]. Natural bioattenuation by the indigenous hydrocarbon degraders, photovolatilization and sorption might have been the contributory factors in the oil loss observed in the control option. Similar trend has been documented [18].

Despite the fact that biostimulation-based bioremediation has been widely published as potent in enhancing bioremediation experiments $[18,10,11]$, the converse has been proven that natural attenuation was more potent than biostimulation in a similar study in Hong Kong [19]. It was also reported that nutrient addition did not significantly enhance bioremediation of polluted soil [20]. However, it was asserted that different soils have different inherent microbial potential to degrade hydrocarbons [21] and the outcome of bioremediation of polluted soil depends on the type of oil and extent of pollution, properties of oil as modified overtime by physical and chemical processes, the organisms and habitats exposed and the nature of the exposure [22].

Heterotrophic levels and activities of indigenous flora is a bioindicator of the impact of nutrients embedded in organic wastes. In this study, active aerobic bacterial (AHB) counts increased notably throughout the 42-day study period (Figure 2) in both the control and amended options. However,
AHB counts were significantly higher $(\mathrm{P} \leq 0.05)$ in the amended options. A similar study on diesel degradation using cowpea chaff [23] recorded a lower AHB counts of $8.0 \times 10^{6}-$ $30.0 \mathrm{x} 10^{6} \mathrm{CFU} / \mathrm{g}$. similarly, HUB counts were significantly higher $(\mathrm{P} \leq 0.05)$ in all the amended options when compared with the control option (Figure 3). It was observed, however that AHB counts was greater than HUB counts. Similar trend has been documented [24]. Hydrocarbon-utilising bacteria are therefore a group of AHBs that evolved possibly as a result of frequent hydrocarbon spills. The HUB isolated in this study were identified tentatively as Corynebacterium sp., Bacillus licheniformis, Micrococcus varians, Pseudomonas putida, Staphylococcus sp and Bacillus cereus (Table 2). These bacteria have been widely reported [7, 24, 25] as having hydrocarbon-utilisation attributes. Fungal counts increased also within the study period but the counts were not significantly higher $(\mathrm{P} \leq 0.05)$ (Figure 4) in the amended option than the control option as was noted in their bacterial counterparts. Also, fungi isolated in the present study were identified tentatively as Fusarium sp., Aspergillus niger, Aspergillus flavus, Cladosporium sp. and Penicillium sp. (Table 3) These have also been reported by several researchers $[25,26]$ as being implicated in hydrocarbon degradation

The observation of higher fungal and bacterial counts in the amended options was possibly due to amendment with PD. Organic wastes such as PD are a reservoir of different hydrocarbon-degrading bacteria and fungi with inherent hydrocarbon-degrading attributes. It stands to reason therefore, that organic amendment is 'uncontrolled bioaugmentation'. The bacterial actors were higher in counts than fungi. It was argued in a similar study [27] that despite the fact that fungi and bacteria are the major actors in hydrocarbon remediation, bacteria are more versatile and hence may play more significant role in bioremediation of oilpolluted soil.

Generally, in similar literatures, reports on bioremediation results and microbial counts have been widely divergent. Several factors such as nature and type of organic wastes, soil structure, length of bioremediation period and constituents of the hydrocarbon pollutant may be responsible for the consistently observed variations.

Seed germination studies have been proposed as a criteria for the assessment of the efficiency of a bioremediation process [13]. In the present study, the highest germination index was noted in the amended option and at the highest amendment level (Table 4). The germination index recorded in the present study followed the same pattern of result as seen in microbial 
counts and bioremediation levels (Table 4). There was 100\% germination in the positive control soil while $1 \%$ germination was recorded in the negative control soil (Table 4). This was probably due to absence of oil pollution in the positive control soil and oil pollution in the negative control soil. Soil pollution with hydrocarbons was reported by different researchers [28, 29] as having adverse effects on plant development parametres. Growth of all seeds of Moringa olifera was recorded in the positive control option [30]. A $99.6 \%$ germination was also noted in the positive control option [29]. Phaseolus vulgaris normally germinates within 8-10 days but the germination was delayed to 19-21 days owing to slightly heavy pollution simulated in this study $(10 \%)$ which had not been fully remediated $(48.54 \%)$ as at the end of the 42-day study period.

There was a significant difference in bioremediation level and microbial counts $(\mathrm{P} \leq 0.05)$ between $\mathrm{PD}$-amended soil and control even at $10 \%$ and $15 \%$ level but not at 5\% amendment level.

\section{CONCLUSION}

From the foregoing, it was found that pig droppings obviously enhanced oil loss from polluted soils with concomitant increase in microbial counts. Pig droppings, therefore can be considered a good alternative biostimulatory candidate for bioremediation of polluted soil.

\section{ACKNOWLEDGEMENT}

The authors are indebted to Dr V.N. Chigor of the Department of Microbiology, University of Nigeria, Nsukka for allowing them access into his Laboratory for space and equipment.

\section{REFERENCES}

[1] Adeleye, A.O., Nkereuwem, M.E., Omokhudu, G.I., Amoo, A.O., Shiaka, G.P. and Yerima, M.B. (2018). Effects of microorganisms in the bioremediation of spent engine oil and petroleum related environmental pollution. J. Appl. Sci. Environ. Manage. 22 (2): 157-167

[2] Wolicka D., Suszek A., Borkowski A. and Bielecka A. 2009. Application of aerobic microorganisms in bioremediation in situ of soil contaminated by petroleum products. Bioresour. Technol., 100, 3221-3227

[3] Agarry, S.E. and Latinwo, G.K. (2015). Biodegradation of diesel oil in soil and its enhancement by application of bioventing and amendment with brewery waste effluents as biostimulationbioaugmentation agents. Journal of Ecological Engineering.16(2):82-91
[4] April T.M., Foght J.M. and Currah R.S. 2000. Hydrocarbon degrading filamentous fungi isolated from flare pit soils in northern and western Canada. Canadian J. Microbiol., 46 (1), $38-49$

[5] Agamuthu, P., Dadrasnia, A. (2013). Potential of biowastes to remediate diesel fuel contaminated soil, Global NEST Journal, 15(4), 474-484.

[6] Adesodun J.K., Mbagwu J.S.C. (2008), Biodegradation of waste-lubricating petroleum oil in a tropical alfisol as mediated by animal droppings, Bioresource Technology, 99(13), 56595665 .

[7] Onuoha, S.C. (2013).stimulated biodegradation of spent lubricating motor oil in soil amended with animal droppings. Journal of Natural Sciences Research,3 (12), 106-116

[8] APHA (2008) American Public Health Association, Standard Methods for the Examination of Water and Wastewater, $21^{\text {st }}$ Edition, Washington DC.

[9] Aremu, M. O., Araromi, D. O. and Gbolahan, O.O. (2015).Regeneration of used lubricating engine oil by solvent extraction process. International Journal of Energy and Environmental Research, 3(1):1-12

[10] L.O. Odokuma and M.N. Ibor. Nitrogen fixing bacteria enhanced bioremediation of crude oil polluted soil. Glob. J. Pur. Appl. Sci., Vol. 8(4),455-468. 2002

[11] Nwogu, T.P., Azubuike,C.C. and Ogugbue, C.J. (2015). Enhanced bioremediation of soil artificially contaminated with petroleum hydrocarbons after amendment with Capra aegagrushircus(goat) manure. Biotechnology research international. 2015:22-29

[12] Tsuneo, W. (2002).Pictorial atlas of soil and seed fungi; Morphologies of cultured fungi and key to species.Second edition, CRC press, Boca Raton, London, Newyork. Washington D.C. Pp 1120-1125

[13] Jaqueline, M.C., Paulo, R.M., Renato, N.M., Ivo, S.T., Natalia, M.G.S. and Ederio, D.B. (2013). Toxicity assessment of contaminated soil using seeds as bioindicators. Journal of Applied Biotechnology. 1(1):34-40

[14] Millioni, V.S., Servulo, E.L.C., Sobral, L.G.S. and De Carvalho, D.D. (2009). Bioremediation of crude oil-bearing soil: evaluating the effect of Rhamnolipid addition to soil toxicity and to crude oil biodegradation efficiency. Global NEST journal.11(2):181-188

[15] Thapa, B., Ajay, K.C.K. and Ghimere, A. (2012). A review on bioremediation of petroleum hydrocarbon contaminants in soil. Kathmandu University Journal of science, Engineering and Technology. 8(1):164-170

[16] Abioye, O. P., Agamuthu, P., and AbdulAziz, A. R. (2012).Biodegradation of used motor oil in soil using organic wastes amendment.Biotechnology Research International. doi:10.1155/2012/587041

[17] Margesin, R.andSchinner, F.(2001).Bioremediation (natural attenuation and biostimulation) of diesel-oil-contaminated soil 
in an alpine glacier skiing area.Applied Environmental Microbiology. 67, 3127-3133

[18] Dadrasnia, A. and Agamuthu, P. (2010).Enhanced degradation of diesel-contaminated soil using organic wastes.Malaysian Journal of Science.29, 225-230.

[19] Bento, F.M., Camargo, F.A.O., Okeke, B.C. and Frankenberger, W.T. (2005). Comparative bioremediation of soils contaminated with diesel oil by natural attenuation, biostimulation and bioaugmentation. Bioresource Technology. 96(9): 1049-1055

[20] Seklemova, E., Pavlova, and A.and Kovacheva, K. (2001) .Biostimulation-based bioremediation of diesel fuel: field demonstration, Biodegradation, 12(5): 311-316.

[21] Padayachee, D. and Lin, J. (2011). The effect of fertilizer amendment on diesel biodegradation in contaminated soils. African Journal of Microbiology Research. 5(14):1729-1739

[22] Ubalua, A.O. (2011). Bioremediation strategies for oil-polluted marine ecosystems.Australian Journal of Agricultural Engineering. 2(6), 160-168.

[23] Stephen, E., Job, O.S. and Abioye, O.P. (2013).Study on biodegradation of diesel contaminated soil amended with cowpea chaff. J. Sci.Multidiscip. Res. 2(1)14-18.2013

[24] Akpe, A. R., Ekundayo, A. O., Aigere, S.P. and Okwu, G. I.(2015). Bacterial degradation of petroleum hydrocarbons in crude oil polluted soil amended with cassava peels. American Journal of Research Communication, 3(7), 99- 118

[25] Stephen, E. and Temola, O.E. (2014). Enhanced biodegradation of spent lubricating oil contaminated soil using poultry litter. British Biotechnology Journal, 4(8), 868-876

[26] Chaudhry, S.,Luhack, J. Sharma, V. and Sharma, C. (2012). Assessment of diesel-degrading potential of fungal isolates from sludge soil of petroleum refinery, Haryana. Res. J.Microbiol. 28: 1-9.

[27] Chikere, C.B., Okpokwasili, G.C. and Chikere, B.O. (2011). Monitoring of hydrocarbon remediation in soil. Biotechnology.1(3):117-138

[28] Ogbo, E.M. (2009). Effects of diesel fuel contamination on seed germination of four crop plants-Arachishypogaea, Vignaunguiculata,Sorghum bicolor, andZea mays. African Journal of Biotechnology. 8:(2):250-253

[29] Okechalu, O.B., Oke, F.M., Egbere, O.J. and Okechalu, J.N. (2014). Effects of biostimulation with organic amendment on the growth and yield of maize (Zea mays) in diesel oil-polluted soil. Journal of Pharmacy and Biological Sciences. 8:40-44

[30] Agbogidi, O.M. and Ilondu, E.M. (2013). Effects of spent engine oil on the germination and seedling growth of Moringaolifera (Lam.). Scholarly Journal of Agricultural Science. 3(6):293-243 